not accept a notice of a private Bill for publication, nor the Clerk of the House accept notice of such, unless the controlling body of the profession endorse the application. Now Mr. Taschereau appears with a Bill which provides that all students enrolled before September, 1903 , in any university of the province, shall be admitted to practise and be licensed by the College of Physicians and Surgeons. This would have admitted 250 men who had not thought it worth while to conform to the requirements, or who had been unable to meet the established tests.

In explaining his Bill $\mathrm{Mr}$. Taschereau said that there were many medical students both at McGill and Laval Universities who had been led by prominent members of the profession to believe that if they continued with their medical studies the Legislature would regularize their original failure to qualify as students, provided they passed their finals in medicine satisfactorily. He contended that after years of study given by students it would be manifestly unfair to refuse them the right of admission to the profession and to apply rigorously to them the decision arrived at last session to pass no more Bills of this nature. The whole question hinges upon the matriculation examinations, upon entering the course of study, and Mr. Taschereau's contentions are inaccurate for the regulations are printed and in the hands of the McGill students, and are well known by the Javal men. Further, one-fourth of those who are following the medical course at McGill are above the provincial regulation, in that they have taken a B.A. degree, and of the remainder those who intend to practise in quebec have taken the necessary examinations.

The medical societies, French and English, of Montreal, Quebec, and Sherbrooke held special meetings and sent delegates to the Legislature, headed by Dr. Lachapelle, President of the Board of Physicians and Surgeons, and as a result the Bill was modified to pass those men who, having made a complete course of classical studies before November ist, 1903, and having passed the required examinations for the Baccalaureate, had obtained an average standing of 50 per cent.; or, if having only one of the above inscriptions, had passed the examination for the other before the College of Physicians and Surgeons. This change was quite as much as could be expected, for it is understood that the candidates most interested had a very influential political backing - at all events it disqualifies over two hundred of those seeking a short cut to medical practice.

Canadian Medical Association.

Arrangements for the thirty-seventh annual meeting of the Canadian Medical Association, to be held at Vancouver on August 23rd to 26th, are almost complete, and the reduced railway rates have just been published. From Halifax to Vancouver the fare will be $8 \mathrm{r}$ dols., with intermediate places in proportion. Special inducements have been held out to members wishing to see the Exposition at St. Louis. Mr. Mayo Robson will be a guest of the Association, as well as Dr. J. W. Mayo, of Rochester (Minn.), and probably Professor Marmorek, who is to be in Montreal during the summer.

$$
\text { Queen's University, Kingston. }
$$

At Queen's University, Kingston, 37 students have passed their final medical examinations, and have been granted the degree of M.D. The Medal in Medicine was won by $H$. Tandy, B.A., and that in Surgery by W. Gibson. The number -of students enrolled in medicine was 216 , and of these 37 held the degree of B.A. upon admission. The results of the London Medical College have also been announced. Eighteen graduated with the degree, and E. Spence received the gold medal ; A. J. Manard, who was a close second, obtained the silver medal.

Waterborne TyPHOID.

The most interesting instance of an epidemic due to water pollution that has come to the notice of public health officials in Canada for a long time occurred in the city at Kingston, where typhoid was rife for some weeks. 'Ihe Kingston city water supply is derived from the St. Lawrence river by an iron pipe, whose intake is $1,500 \mathrm{ft}$. from the shore, and this pipe is laid simply on the bottom of the river, passing as it does through a zone where the water is contaminated by the outlet of the city sewage system. Samples of water taken from the tap on analysis showed colon bacilli and streptococci in many samples, giving presumptive evidence of sewage contamination. Samples of water taken from the river at the intake and for some distance inland were innocuous, but nearer the shore showed the organisms. Acting on this evidence the pipe was examined, and after careful search a large opening was found some $500 \mathrm{ft}$. out from shore. On inquiry it was found that during the previous fall a vessel had had its anchor foul there and had attempted to pull it up by tugs, but the cable had broken and the anchor was left and was found at the leak. The break allowed a comparatively large quantity of inshore water to enter the conduit. The opening was stopped up and in a couple of weeks the new cases of typhoid became much fewer, while the analysis after the repair showed almost complete absence of the colon bacillus. This incident shows the importance attaching to the discovery of this bacillus under such circumstances in drinking water.

Tinned Foods and "Improved" Milk.

During the month of April a series of thirty-four examinations were undertaken by the Laboratory of the Provincial Board of Health of Ontario; twenty-three of these were on canned vegetables, fruits, and jams, and all were the product of Ontario canneries and of the cheaper grades, for example, those which sell for ten cents a jar. None of them showed poisonous metals in harmful quantities; metals, indeed, were present, especially zinc and copper, but these are incidental to the process of manufacture, namely, the preserving in cans. None of the ordinary preservatives were found. Seasonings and flavourings were few. The cheap jams were filled with apple or turnip pulp, only enough of the iruit being present in some cases to give a seed here and there throughout the mass. Aniline dyes were used for colouring purposes.

A specimen of "cream albumenoid" " I lb. of which added to 28 gallons of thin cream will produce 32 gallons of thick cream "was sent by the Medical Health Officer of Hamilton. It was found to contain cane sugar, lime, and gelatine, and was used to "improve" milk.

Bacterioloritcal Diagnosis.

Dr. W. T. Connell, of Kingston, has been appointed Assistant Becteriologist for Ontario, and will undertake the examination of specimens from the eastern part of the province, thus permitting more rapid returns. At the central laboratory 344 specimens were examined in April.

\section{MEDICAL ASPECTS}

OF THE RUSSO-JAPANESE WAR. By Sir Frederick Treves, Bart., K.C.V.O. Tokyo, Japan, May 1st, 1904.

Wouxded Russiax Sailors at Hong Kong. During my stay at Hong Kong I visited, with Dr. Atkinson, the principal medical officer of the colony, the wounded Russian sailors who had just come down from the action at Chemulpo. They were in the General Hospital and were all doing well. Their injuries were mostly shell wounds and wounds from splinters. One case only was serious, and in this instance the tissues of the forearm had been much torn up by a flying fragment. The men were all of exceptionally fine physique, and they lost no opportunity of expressing their satisfaction with their surroundings. The sisters said they made excellent patients, and it was wonderful how easily everything was managed, considering that their language was intelljgible to none. I also saw, at the request of the Italian commander, a young Russian officer who had been wounded in the same engagement, and who was lying on board the Italian cruiser Elba. He had a severe lacerated wound from a shell fragment over the front of the knee, but the joint had fortunately escaped. He was doing well, and was moved to the Colonial Hospital at Hong Kong as soon as the necessary permission was obtained. At Hong Kong I had an opportunity of seeing the very ample and admirable arrangements made by Dr. Atkinson for the treatment of infectious disease and for meeting the annual visitation of plague. In addition to a very large new hospital, there is an excellent hospital ship.

A new military hospital is in process of building on the hillside at Hong Kong, and it promises, when completed, to be one of the finest hospitals of its size in the service. 
Mobilization in Japan.

In Japan there is very little evidence that this wonderful nation is at war. Steamers have to be piloted into the harbours of Nagasaki and Yokohama on account of the mines laid in those places. In the inland sea six transports passed us all laden with troops, and the strange wooden erections which hamper the decks of such vessels were precisely similar to those which were so very familiar at Capetown and Durban in 1899. All over the country mobilization is being carried on, but very quietly and methodically. As the railways are very largely taken over for military purposes, travelling for the ordinary person is slow and uncertain, and a journey of 100 miles may very easily take fifteen hours. Moreover, all sleeping and dining carriages have vanished since the war began.

Most excellent arrangements are made by the Red Cross and other societies to secure every possible comfort for the soldier on his way to the transport, and no opportunity is lost to give him a good "send off." At a level crossing on the railway, as it passes through a small town, will often be a placard to indicate at what hours trains with soldiers for the front are passing by. When the train does pass, the little town turns out with flags of all kinds, and very hearty cheering and expressions of good wishes, so that the soldier-on what may possibly be his last journey through Japan-has a very royal reception the whole way, from the dépôt to the sea. Seeing a train off, full of men for the front, is much the same, whether the station be at Kyoto or at Waterloo.

The Japanese Medical Service.

Thanks to the kindness of Surgeon-General Koike, the Director-General of the Army Medical Service, I was able to visit military hospitals and to learn something of the organization of the service be so ably controls. There is at Tokyo also Lieutenant-Colonel Macpherson, R.A.M.C., who is the medical attaché appointed by the English War Office, and his report of the condition of the Japanese Army Medical Service will be of great value and interest. Nursing sisters are not employed by the Japanese Medical Corps nor indeed have female nurses any part in the organization of the department. The field equipment of the Army Medical Corps in Japan is excellent, light, simple, and inexpensive, and full of ingenious devices in almost every department.

IIn addition to the officers of the corps there are noncommissioned officers who act as ward masters and undertake the duties performed by like officers in the R.A.M.C. The nursing is in the hands of male sick attendants. They are not soldiers, and do not therefore correspond to the orderlies in an English military hospital. To each regiment a certain number of orderlies is attached; the number is small and the men, who are soldiers, correspond rather to the regimental orderly in the home service. Their work is mainly with the bearer sections.

The Japanese Red Cross Society.

In times of war the Red Cross Society supplements the medical work of the service. This society is remarkable in its size, its many branches all over the country, its important work, and its very admirable organization. It is a society of voluntary workers. It has no direct official connexion with the Army Medical Corps, but the utmost use is made of its invaluable services.

It not only maintains hospitals for soldiers in Japan, but it supplies an immense staff of civil surgeons and nurses.
More than that it concerns itself in every way with everything that relates to the comfort of the soldier in times of war. The officers, non-commissioned officers and male sick attendants accompany the troops of the front. The military hospitals in Japan are thus emptied of their staff and are taken over by the Red Cross Society. That Society provides civil surgeons for these hospitals and female nurses. The nurses are, of course, Japanese, and are well trained. Three years' training is required. The Red Cross Society is able to supply through its various branches no less than 3,000 female nurses and 2,000 male nurses. Female nurses will not be sent to the front but will undertake duty in Japan in the military and Red Cross hospitals in various parts of the country. It is needless to say, therefore, that the military authorities need neither surgeons nor nurses and it is difficult to understand how foreign nurses with no knowledge of the language and little insight into Japanese modes of living could be made use of. Pecuniary support to the Red Cross Society is the most practical way of helping the Japanese in their efforts to provide liberally for the sick or wounded soldier.

The Attitude of the People.

During a residence of two months in Japan I have been greatly struck by the admirable bearing of the people-in all classes of society-in connexion with the war. The Japanese are intensely patriotic, but their patriotism is a solemn sentiment and not a temporary neurosis. There is no boasting and no bragging, and no symptom or trace of "Mafficking." In discussing their successes they are always modest, and their attitude towards an enemy who has experienced a temporary reverse is almost sympathetic. If the attitude of a people during a time of war can be discussed as a matter of taste, it may be appropriate to say that the attitude of the Japanese has been characterized by such good taste that it is worthy of imitation.

\section{CONTRACT MEDICAL PRACTICE}

Post Office Medical Appointments.

WE are requested to publish the following letter, which has been addressed to the Medical Secretary of the British Medical Association by the Honorary Secretary of the South Manchester Division :

Dear Sir,-I am instructed by the Executive Committee of the South Manchester Division of the Laneashire and Cheshire Branch to acquaint you with the results of their discussion of the medical appointments recently offered by the Post Office authorities in various parts of the country.

The Committee is of opinion that the fees should be raised from $8 \mathrm{~s}$. 6d. to ros. a year, and that special fees should be paid for special visits under the following paragraphs relating to (I) malingering, (3) and (4) special examinations, (5) superannuation, (6) sanitary reports upon Post Office buildings.

The gross remuneration in each district is very small, and the Committee thinks that the rate of payment should be at least as high as the rate for attendance upon the police force, as the amount of sickness is likely to be proportionally greater.

The Committee suggests that you should make suitable representations to the Postmaster-General in furtherance of these changes in the scale of remuneration. Signed for the Committee, Percy McDougall, M.B., Honorary Secretary and Treasurer.

SURGEON's Position on Dissolution OF BENEFIT SOCIETY. A CoRRESPONDENT writes that he has been surgeon to a benefit society in connexion with some lead mines for thirtean years. He was paid on the ordinary contract system at the rate of $5 \mathrm{~s}$. per annum per member residing in his district. The lead mines have now ceased working, and the benefit society is about to be dissolved, the accumulated funds being divided among the members. He wishes to know whether he can claim any compensation for the abolition of his office: or onlv arrears of salary up to the time of dissolution with an allowance in lieu of notice.

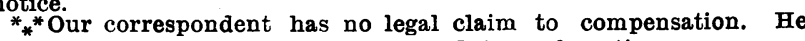
will be entitled to arrears of salary and to such notice-or compensatory payment-as is due to him under the agreement on which he was elected. 